\title{
Analysis of Genotype by Environmental Interaction and Stability for Grain Yield of Faba Bean (Vicia Faba L.) Genotypes in West and Kellem Wollega Zones of Western Oromia
}

\author{
Dereje Abera*, Biru Alemu, Tashome Gutu \\ Oromia Agricultural Research Inistitute (OARI), Haro Sabu Agricultural Research Center, P.O.Box 10, Kellem \\ Wollega, Dambi Dollo, Ethiopia.
}

\begin{abstract}
*Corresponding Author: Dereje Abera, Oromia Agricultural Research Inistitute (OARI), Haro Sabu Agricultural Research Center, P.O.Box 10, Kellem Wollega, Dambi Dollo, Ethiopia.
\end{abstract}

\begin{abstract}
A field experiment was conducted on fourteen faba bean genotypes at Haro Sabu Agricultural Research Center sub-sites during 2015-2017 main cropping season with the objective to evaluate and select high yielding and stable genotype over test environments that are tolerant to major faba bean diseases. Randomized complete block design with three replications with net plot size of $1.6 \mathrm{~m} \times 3 \mathrm{~m}$ was used. Pooled ANOVA declared significant difference among evaluated genotypes for plant height, number of pods per plant, hundreds seed weight and grain yield. All observed agronomic traits excluding days to flowering and days to maturity showed significant differences across the testing environments. On the other hand, genotype by environment interaction had significant effect on number of pods per plant and grain yield. Stability parameters were estimated by employing AMMI stability Value, Genotype selection Index and explained by GGE biplot. The total variation of $45.55 \%, 6 \%$ and $22.51 \%$ were contributed by environment, genotypes and genotype by environment interaction for grain yield, respectively. G10 (16.74Qt/ha) and G12 (16.32Qt/ha) were identified for their better yield performance with yield advantage of 5.42 and $2.77 \%$, respectively over the best standard check (Shalo=15.88Qt/ha). G10 and G12 had better mean value of thousand seed weight viz. $76.78 \mathrm{gram}$ (G10) and $73.90 \mathrm{gm}$ (G12) over Shalo (62.87 gram). AMMI biplot, ASV, GSI and GGE Biplot further confirmed that G10 and G12 were most stable and widely adapted genotypes. Therefore, the identified genotypes (G10 and G12) were suggested to be released as new varieties for West and Kelem Wollega Zones and areas with similar agro-ecology.
\end{abstract}

Keywords: Faba bean, Stability, Yield

\section{INTRODUCTION}

Faba bean (Vicia faba L.) is an important pulse crop grown in highlands of Ethiopia, where the soil and weather are considered to be congenial for better growth and development of the crop. The crop shares the largest area under pulses production in Ethiopia [1]. Faba bean is a crop of manifold merits in the economy of the farming communities in the highlands of Ethiopia and serves as income and source of food to farmers, earns foreign exchange to country, and plays a significant role in soil fertility restoration in crop rotation through fixation of atmospheric nitrogen.

The crop is mainly produced in Tigray, Gondar, Gojjam, Wollo, Wollega, Shoa and Gamo-Gofa regions of Ethiopia [5]. Nevertheless, faba bean production in Ethiopia is constrained by stress like water logging, low yielding indigenous cultivars [1] and other stresses like diseases [2]. Correspondingly, the yield potential of faba bean has not been exploited in West and Kelem Wollega Zones of Western Oromia which might be attributed due to low yielding local cultivar usage by farmers and disease stresses prevalence in the locality. In order to uplift the production and productivity of the crop; screening of faba bean genotypes that withstands major production constraints in the area is crucial. Therefore, the study was conducted to identify and develop stable and high yielding varieties that are tolerant to major faba bean diseases in the study areas of West and Kelem Wollega Zones and other areas having similar agro-ecologies

\section{Materials AND Methods}

\subsection{Description of the Study Area}

A field experiment was conducted at Haro Sabu Agricultural Research Center sub-sites (Badesso and Mata) for three (2015-2017) consecutive main cropping seasons and one extra site (Lalo Asabi). The 
study sites were recognized with an elevation of 2016 m.a.s.l (Mata) and 2054 m.a.s.l (Badeso) with unimodal rain fall distribution pattern. Besides, these sites had sandy loam type soil textural class with $\mathrm{PH}$ of 4.59 and 5.65 and exchangeable acidity of 0.07 and $0.14 \mathrm{dS} / \mathrm{m}$ for Mata and Badesso, respectively.

\subsection{Testing Genotypes}

Fourteen (14) faba bean genotypes including local check and two standard checks (Shallo and Moti) were evaluated for their performance on grain yield and yield related agronomic traits (Table 1).

Table1. Designation of genotypes

\begin{tabular}{|c|c|c|}
\hline Code & genotype & Hosting Center \\
\hline G1 & Ek02016-1-4 & Holeta Agricultural Research Center \\
\hline G2 & EK02018-1 & Holeta Agricultural Research Center \\
\hline G3 & Eh06005-1 & Holeta Agricultural Research Center \\
\hline G4 & Ek 01019-7-1 & Holeta Agricultural Research Center \\
\hline G5 & Local check & Holeta Agricultural Research Center \\
\hline G6 & Eh00126-2 & Holeta Agricultural Research Center \\
\hline G7 & EKLS01022-1 & Holeta Agricultural Research Center \\
\hline G8 & Eh00009-3 & Holeta Agricultural Research Center \\
\hline G9 & EKIsr01009-2-2 & Holeta Agricultural Research Center \\
\hline G10 & Eh00016-2 & Standard Check \\
\hline G11 & Moti & Holeta Agricultural Research Center \\
\hline G12 & Eh06079-7 & Standard Check \\
\hline G13 & Eh000012-4 & \\
\hline
\end{tabular}

Key: G=genotype

\subsection{Experimental Design}

Randomized Complete Block Design (RCBD) with three replications, having a net plot size of $1.6 \mathrm{mx} 3 \mathrm{~m}$ each consisting of four harvestable rows was used. Six rows with $40 \mathrm{~cm}$ between rows and $10 \mathrm{~cm}$ between plants were used for the experiment with the seed rate of $135 \mathrm{~kg} / \mathrm{ha}$. Inorganic fertilizer DAP was applied at the rate of $100 \mathrm{~kg} / \mathrm{ha}$ at sowing time. All agronomic practiceswere done as uniformly as required.

\subsection{Data Collection}

Agronomic data were collected on plot and plant basis. Some of the data taken were number of pods per plant, number of seeds per pod, plant height in centimeter, days to $50 \%$ flowering, days to physiological maturity, thousand seed weight, grain yield and major faba bean disease (Chocolate leaf spot)

\section{RESULTS AND DISCUSSIONS}

\subsection{Analysis of Variance}

Analysis of variance (ANOVA) was done for grain yield and seven yield related traits. The collected data were organized and analyzed using SAS statistical package [6]. Homogeneity of variance was tested and combined analysis was done using general linear model (Proc GLM) procedure to estimate contribution of genotype, environment and their interaction towards total variation. Mean separation was done using least significant difference (LSD) employing the procedure developed by Gomez and Gomez [4], whereas GGE biplot and AMMI stability analysis was done using GenStat computer software (2012). Combined analysis of variance showed significant $((\mathrm{P} \leq 0.01)$ yield difference among genotypes, environments and their interaction for grain yield (Table 2). The significant interaction effect of genotype $\times$ environment showed that the evaluated genotypes responded differently to the variation in environmental conditions. The same finding was reported so far [5].

Table2. Combined Mean square of yield and related agronomic traits of Faba bean genotype

\begin{tabular}{|c|c|c|c|c|c|c|c|c|}
\hline \multirow{2}{*}{$\begin{array}{c}\text { Source of } \\
\text { Variation }\end{array}$} & \multirow{2}{*}{ DF } & \multicolumn{9}{|c|}{ Mean Square } \\
\cline { 3 - 9 } & & DF & DM & PH & PPP & SPP & HSW & GY \\
\hline Geno & 13 & 10.99 & 6.98 & $1054.6^{*}$ & $28.28^{* *}$ & 0.14 & $523.58^{* *}$ & $35.67^{* *}$ \\
\hline Rep & 2 & 39.47 & 27.12 & 136.30 & 6.90 & 0.13 & 38.28 & 49.23 \\
\hline Env & 6 & 31.99 & $298.6^{* *}$ & $10779^{* *}$ & $70.00^{* *}$ & $2.32^{* *}$ & $1983.26^{* *}$ & $262.18^{* *}$ \\
\hline
\end{tabular}


Analysis of Genotype by Environmental Interaction and Stability for Grain Yield of Faba Bean (Vicia Faba L.) Genotypes in West and Kellem Wollega Zones of Western Oromia

\begin{tabular}{|c|c|c|c|c|c|c|c|c|}
\hline $\mathrm{G}^{*} \mathrm{E}$ & 52 & 12.22 & 5.49 & 302.34 & $7.16^{*}$ & 0.33 & 79.60 & $22.69^{* *}$ \\
\hline Error & & 14.13 & 4.85 & 390.64 & 3.80 & 0.29 & 117.61 & 10.02 \\
\hline
\end{tabular}

Key: $-D F=$ days to flowering, $D M=$ days to maturity, $P H=$ plant height, $P P P=$ number of pods per plant, $S P P$ =number of seeds per pod, HSW =hundred seed weight, GY = grain yield

\subsection{Mean Performance of Grain Yield And Yield}

Plant height ranged from $142 \mathrm{~cm}(\mathrm{G} 6)$ to $165.43 \mathrm{~cm}$ (G9) with over all mean value of $156.35 \mathrm{~cm}$. On the other hand, G10, G11 and G14 had higher number of pods per plant than the rest. Higher mean value of thousand seed weight was recorded from all faba bean genotypes over Shallo which had a mean value of $62.87 \mathrm{gram}$ (Table 3$)$. The minimum (10.14 Qt/ha) and maximum (21.08 Qt/ha) mean value of grain yield was obtained at environment 2 and environment 4 , respectively with mean value of $14.72 \mathrm{Qt} / \mathrm{ha}$ (Table 4). On the other hand, the pooled analysis detected the lowest $(12.44 \mathrm{Qt} / \mathrm{ha})$ and highest (16.74 Qt/ha) mean value of grain yield from G8 and G10, respectively with over all mean value of $14.72 \mathrm{Qt} / \mathrm{ha}$. The highest mean of grain yield was exhibited by G10, and followed by G12 and G13. Yield advantage of 5.42 and $2.77 \%$ was estimated for G10 and G12, respectively over the best standard check Shalo (Table 3).

Table3. Combined mean performance of grain yield and yield related traits of genotype

\begin{tabular}{|c|c|c|c|c|c|c|c|c|c|c|}
\hline $\begin{array}{c}\text { Cod } \\
\text { e }\end{array}$ & genotype & DF & DM & PH & PPP & SPP & $\begin{array}{c}\text { HSW } \\
(\text { gm })\end{array}$ & $\begin{array}{c}\text { GY(Qt/h } \\
\text { a) }\end{array}$ & $\begin{array}{c}\text { YAD } \\
(\%)\end{array}$ & $\begin{array}{c}\text { DR (Chocolate } \\
\text { spot) }\end{array}$ \\
\hline G1 & Ek02016-1-4 & $46.95 \mathrm{ab}$ & $132.52 \mathrm{~b}$ & $148.36 \mathrm{de}$ & $7.04 \mathrm{~g}$ & $3.09 \mathrm{a}$ & $75.46 \mathrm{ab}$ & $13.13 \mathrm{ef}$ & -17.32 & 2.67 \\
\hline G2 & EK02018-1 & $47 \mathrm{ab}$ & $132.86 \mathrm{~b}$ & $154.43 \mathrm{~b}-\mathrm{e}$ & $7.07 \mathrm{~g}$ & $3.12 \mathrm{a}$ & $75.36 \mathrm{ab}$ & $14.26 \mathrm{c}-\mathrm{f}$ & -10.2 & 2.46 \\
\hline G3 & Eh06005-1 & $47.29 \mathrm{ab}$ & $133.81 \mathrm{ab}$ & $148.59 \mathrm{de}$ & $8.11 \mathrm{e}-\mathrm{g}$ & $3.15 \mathrm{a}$ & $74.07 \mathrm{a}-\mathrm{c}$ & $14.31 \mathrm{c}-\mathrm{f}$ & -9.89 & 2.71 \\
\hline G4 & Ek 01019-7-1 & $47.57 \mathrm{ab}$ & $132.95 \mathrm{~b}$ & $157.13 \mathrm{a}-\mathrm{d}$ & $8.5 \mathrm{c}-\mathrm{f}$ & $3.12 \mathrm{a}$ & $78.76 \mathrm{ab}$ & $14.9 \mathrm{a}-\mathrm{e}$ & -6.17 & 2.29 \\
\hline G5 & Local check & $47.48 \mathrm{ab}$ & $133.33 \mathrm{ab}$ & $161.23 \mathrm{a}-\mathrm{c}$ & $9.18 \mathrm{~b}-\mathrm{e}$ & $3.14 \mathrm{a}$ & $68.53 \mathrm{c}-\mathrm{e}$ & $13.71 \mathrm{ef}$ & -13.66 & 2.4 \\
\hline G6 & Eh00126-2 & $47.05 \mathrm{ab}$ & $132.57 \mathrm{~b}$ & $142.74 \mathrm{e}$ & $8.32 \mathrm{ef}$ & $3.08 \mathrm{a}$ & $72.65 \mathrm{~b}-\mathrm{d}$ & $13.5 \mathrm{ef}$ & -14.99 & 2.63 \\
\hline G7 & EKLS01022-1 & $47.24 \mathrm{ab}$ & $132.81 \mathrm{~b}$ & $159.75 \mathrm{a}-\mathrm{d}$ & $8.7 \mathrm{c}-\mathrm{e}$ & $3.18 \mathrm{a}$ & $79.42 \mathrm{a}$ & $14.73 \mathrm{~b}-\mathrm{e}$ & -7.24 & 2.50 \\
\hline G8 & Eh00009-3 & $45.62 \mathrm{~b}$ & $133.29 \mathrm{ab}$ & $157.28 \mathrm{a}-\mathrm{d}$ & $7.4 \mathrm{fg}$ & $3.24 \mathrm{a}$ & $79.65 \mathrm{a}$ & $12.44 \mathrm{f}$ & -21.66 & 3.04 \\
\hline G9 & EKIsr01009-2-2 & $47.38 \mathrm{ab}$ & $133.05 \mathrm{ab}$ & $165.43 \mathrm{ab}$ & $8.47 \mathrm{~d}-\mathrm{f}$ & $3.33 \mathrm{a}$ & $76.42 \mathrm{ab}$ & $14.06 \mathrm{~d}-\mathrm{f}$ & -11.46 & 2.42 \\
\hline G10 & Eh00016-2 & $48.14 \mathrm{a}$ & $133.86 \mathrm{ab}$ & $158.44 \mathrm{a}-\mathrm{d}$ & $10.07 \mathrm{ab}$ & $3.18 \mathrm{a}$ & $76.78 \mathrm{ab}$ & $16.74 \mathrm{a}$ & 5.42 & 2.21 \\
\hline G11 & Moti & $47.05 \mathrm{ab}$ & $133.62 \mathrm{ab}$ & $151.2 \mathrm{c}-\mathrm{e}$ & $9.96 \mathrm{ab}$ & $3.2 \mathrm{a}$ & $66.53 \mathrm{de}$ & $15.87 \mathrm{a}-\mathrm{d}$ & -0.06 & 2.38 \\
\hline G12 & Eh06079-7 & $45.76 \mathrm{~b}$ & $133.29 \mathrm{ab}$ & $166.57 \mathrm{a}$ & $9.6 \mathrm{a}-\mathrm{d}$ & $3.22 \mathrm{a}$ & $73.91 \mathrm{a}-\mathrm{c}$ & $16.32 \mathrm{ab}$ & 2.77 & 1.92 \\
\hline G13 & Eh000012-4 & $47.19 \mathrm{ab}$ & $133.86 \mathrm{ab}$ & $159.03 \mathrm{a}-\mathrm{d}$ & $9.67 \mathrm{a}-\mathrm{c}$ & $3.33 \mathrm{a}$ & $74.01 \mathrm{a}-\mathrm{c}$ & $16.18 \mathrm{a}-\mathrm{c}$ & 1.89 & 2.25 \\
\hline G14 & Shalo & $47.43 \mathrm{ab}$ & $134.38 \mathrm{a}$ & $158.66 \mathrm{a}-\mathrm{d}$ & $10.44 \mathrm{a}$ & $3.21 \mathrm{a}$ & $62.87 \mathrm{e}$ & $15.88 \mathrm{a}-\mathrm{d}$ & 0 & 2.58 \\
\hline & Mean & 47.08 & 133.3 & 156.35 & 8.75 & 3.18 & 73.89 & 14.72 & & 2.46 \\
\hline & CV & 7.99 & 1.65 & 12.64172 & $\mathbf{2 2 . 2 7}$ & 17.03 & 14.63 & 21.5 & & 26.08 \\
\hline & Lsd & 2.29 & 1.34 & 12.03 & 1.19 & 0.33 & 6.58 & 1.93 & & 0.52 \\
\hline
\end{tabular}

Key: Whereas, $D F=$ days to flowering, $D M=$ Days to maturity, $P H=$ Plant height, $P P=P o d /$ plant, $S P P=$ Seed/pod, HSW=Hundred seed weight, YAD (\%) = Percent of yield advantage, DR= Disease reaction, CV= Coefficient of variation, Lsd= least significant difference, GXE= Interaction of genotype by environment

The mean grain yield of the tested genotype at the testing sites showed significant variation. From the pooled data, two genotypes, EH00016-2 (16.74Qt/ha) and EH 06079-7 (16.32Qt/ha) gave relatively higher yield than the standard check, Shallo (15.88Qt/ha). Tolessa (2015) reported that the varieties responded differentially in southeastern and central Oromia [9], while (Tadesse and Abay, 2011) noted the same trend on sesame in northern Ethiopia [7].

Table4. Grain yield (Qt/ha) performance of faba bean genotypes over each seven environments

\begin{tabular}{|c|c|c|c|c|c|c|c|c|c|}
\hline Code & genotype & 1 BD & 1 MT & 2BD & 2MT & 3MT & 3BD & 1 TA & Comb \\
\hline G1 & Ek02016-1-4 & $9.27 \mathrm{a}-\mathrm{c}$ & $7.12 \mathrm{c}$ & $13.26 \mathrm{~b}-\mathrm{d}$ & $18.51 \mathrm{de}$ & $15.7 \mathrm{~b}-\mathrm{d}$ & $8.29 \mathrm{~h}$ & $19.8 \mathrm{a}-\mathrm{c}$ & $13.13 \mathrm{ef}$ \\
\hline G2 & EK02018-1 & $14.26 \mathrm{ab}$ & $9.74 \mathrm{a}-\mathrm{c}$ & $12.1 \mathrm{~cd}$ & $18.34 \mathrm{de}$ & $14.35 \mathrm{~cd}$ & $11.62 \mathrm{fg}$ & $19.37 \mathrm{a}-\mathrm{d}$ & $14.26 \mathrm{c}-\mathrm{f}$ \\
\hline G3 & EH06005-1 & $14.66 \mathrm{a}$ & $8.67 \mathrm{bc}$ & $17.6 \mathrm{a}-\mathrm{d}$ & $19.09 \mathrm{c}-\mathrm{e}$ & $14.19 \mathrm{~cd}$ & $8.97 \mathrm{gh}$ & $16.97 \mathrm{a}-\mathrm{e}$ & $14.31 \mathrm{c}-\mathrm{f}$ \\
\hline G4 & Ek 01019-7-1 & $9.09 \mathrm{a}-\mathrm{c}$ & $10.33 \mathrm{a}-\mathrm{c}$ & $19.11 \mathrm{a}-\mathrm{c}$ & $22.61 \mathrm{a}-\mathrm{d}$ & $13.6 \mathrm{de}$ & $16.07 \mathrm{c}-\mathrm{e}$ & $13.49 \mathrm{e}$ & $14.9 \mathrm{a}-\mathrm{e}$ \\
\hline G5 & Local check & $6.38 \mathrm{c}$ & $13.85 \mathrm{a}$ & $15.63 \mathrm{a}-\mathrm{d}$ & $18 \mathrm{de}$ & $13.8 \mathrm{~cd}$ & $13.3 \mathrm{ef}$ & $15 \mathrm{de}$ & $13.71 \mathrm{ef}$ \\
\hline G6 & Eh00126-2 & $8.45 \mathrm{bc}$ & $11.98 \mathrm{ab}$ & $12.51 \mathrm{~b}-\mathrm{d}$ & $19.05 \mathrm{c}-\mathrm{e}$ & $13.23 \mathrm{de}$ & $11.38 \mathrm{f}-\mathrm{h}$ & $17.91 \mathrm{a}-\mathrm{e}$ & $13.5 \mathrm{ef}$ \\
\hline G7 & EKLS01022-1 & $10.44 \mathrm{a}-\mathrm{c}$ & $9.61 \mathrm{a}-\mathrm{c}$ & $19.42 \mathrm{ab}$ & $21.84 \mathrm{~b}-\mathrm{d}$ & $10.93 \mathrm{e}$ & $15.28 \mathrm{c}-\mathrm{e}$ & $15.62 \mathrm{~b}-\mathrm{e}$ & $14.73 \mathrm{~b}-\mathrm{e}$ \\
\hline G8 & EH00009-3 & $11.9 \mathrm{a}-\mathrm{c}$ & $8.02 \mathrm{bc}$ & $10.31 \mathrm{~d}$ & $14.95 \mathrm{e}$ & $14.29 \mathrm{~cd}$ & $9.33 \mathrm{gh}$ & $18.31 \mathrm{a}-\mathrm{d}$ & $12.44 \mathrm{f}$ \\
\hline G9 & EKIsr01009-2-2 & $8.76 \mathrm{a}-\mathrm{c}$ & $12.34 \mathrm{ab}$ & $11.47 \mathrm{~d}$ & $20.45 \mathrm{c}-\mathrm{e}$ & $13.26 \mathrm{de}$ & $13.94 \mathrm{~d}-\mathrm{f}$ & $18.17 \mathrm{a}-\mathrm{d}$ & $14.06 \mathrm{~d}-\mathrm{f}$ \\
\hline G10 & EH00016-2 & $9.61 \mathrm{a}-\mathrm{c}$ & $12.01 \mathrm{ab}$ & $20.92 \mathrm{a}$ & $24.91 \mathrm{a}-\mathrm{c}$ & $17.8 \mathrm{ab}$ & $16.6 \mathrm{~b}-\mathrm{d}$ & $15.33 \mathrm{c}-\mathrm{e}$ & $16.74 \mathrm{a}$ \\
\hline
\end{tabular}


Analysis of Genotype by Environmental Interaction and Stability for Grain Yield of Faba Bean (Vicia Faba L.) Genotypes in West and Kellem Wollega Zones of Western Oromia

\begin{tabular}{|c|c|c|c|c|c|c|c|c|c|}
\hline G11 & Moti & $12.75 \mathrm{ab}$ & $8.94 \mathrm{bc}$ & $11 \mathrm{~d}$ & $27.87 \mathrm{a}$ & $13 \mathrm{de}$ & $17.3 \mathrm{a}-\mathrm{c}$ & $20.22 \mathrm{a}$ & $15.87 \mathrm{a}-\mathrm{d}$ \\
\hline G12 & EH06079-7 & $11.74 \mathrm{a}-\mathrm{c}$ & $9.84 \mathrm{a}-\mathrm{c}$ & $14.26 \mathrm{a}-\mathrm{d}$ & $19.5 \mathrm{c}-\mathrm{e}$ & $19 \mathrm{a}$ & $19.95 \mathrm{a}$ & $19.95 \mathrm{ab}$ & $16.32 \mathrm{ab}$ \\
\hline G13 & EH000012-4 & $12.68 \mathrm{ab}$ & $6.93 \mathrm{c}$ & $16.07 \mathrm{a}-\mathrm{d}$ & $26.67 \mathrm{ab}$ & $15.19 \mathrm{~b}-\mathrm{d}$ & $19.33 \mathrm{ab}$ & $16.39 \mathrm{a}-\mathrm{e}$ & $16.18 \mathrm{a}-\mathrm{c}$ \\
\hline G14 & Shalo & $9.96 \mathrm{a}-\mathrm{c}$ & $12.53 \mathrm{ab}$ & $16.64 \mathrm{a}-\mathrm{d}$ & $23.3 \mathrm{a}-\mathrm{d}$ & $16.54 \mathrm{a}-\mathrm{c}$ & $14.82 \mathrm{c}-\mathrm{e}$ & $17.32 \mathrm{a}-\mathrm{e}$ & $15.88 \mathrm{a}-\mathrm{d}$ \\
\hline & Mean & 10.71 & 10.14 & 15.02 & 21.08 & 14.63 & 14.01 & 17.42 & 14.72 \\
\hline & CV & 12.60 & 26.86 & 29.02 & 16.57 & 11.62 & 13.30 & 15.62 & 21.50 \\
\hline & Lsd & 6.13 & 4.57 & 7.32 & 5.86 & 2.85 & 3.13 & 4.57 & 1.93 \\
\hline
\end{tabular}

Key: Whereas 1BD=Badesso 2015, 1MT=Mata 2015, 2BD=Badesso 2016, 2MT=Mata 2016, 3MT=Mata 2017, 3BD=Badesso 2017, 1LA= Lalo Asab 2017, CV= Coefficient of variation, Lsd= least significant difference.

\subsection{Additive Main Effect and Multiplicative Interaction Effect (AMMI) Analysis}

Combined analysis of variance declared significant variations of genotypes, environments and genotypes by environment interaction for grain yield and this sign posted unstable response of genotypes and fluctuation of grain yield with environmental change which clearly illustrated the presence of genotype by environment interactions.

Table5. Analysis of variance from AMMI model for grain yield

\begin{tabular}{|c|c|c|c|c|}
\hline Source & Df & SS & MS & Explained Variance (\%) \\
\hline Total & 293 & 7872 & $26.87^{* *}$ & 74.06 \\
\hline Treatments & 97 & 5830 & $60.11^{* *}$ & 6 \\
\hline Genotypes & 13 & 472 & $36.31^{* *}$ & 45.55 \\
\hline Environments & 6 & 3586 & $597.71^{* *}$ & 4.22 \\
\hline Block & 14 & 332 & $23.71^{* *}$ & 40.8 \\
\hline Interactions & 78 & 1772 & $22.72^{* *}$ & 26.4 \\
\hline IPCA & 18 & 723 & $40.18^{* *}$ & 32.8 \\
\hline IPCA & 16 & 467 & $29.18^{* *}$ & \\
\hline Residuals & 44 & 582 & 13.23 & \\
\hline Error & 182 & 1710 & 9.39 & \\
\hline
\end{tabular}

From the total variation obtained for grain yield $6 \%, 45.55 \%$ and $22.51 \%$ were contributed by genotypes; environment and genotype by environment inter action, respectively (Table 5). IPCA1 and IPCA2 attained $40.8 \%$ and $26.4 \%$ interaction sum square and contributed a total of $67.2 \%$ of total variation (Table 5). According to Kempton (1984) in AMMI model the first two interactions principal component axis was a best predictive model that explains the interaction sum of squares. The finding of the study supported Tamane et al. (2015) who reported highly significant ( $\mathrm{p} \leq 0.01)$ difference of genotype, environment and their interaction for grain yield in faba bean genotypes evaluated in multilocation of Ethiopia [8].

\subsection{AMMI Stability Value (ASV) and Genotype Selection Index (GSI)}

In AMMI model, the genotype with least AMMI stability value (ASV) score was considered as the most stable. According to ASV, EKISR01009-2-2, Shalo and EH06079-7 were showed a higher stability (Table 6). As stability per se is not a desirable selection criterion, because the most stable genotypes would not necessarily give the best yield performance, hence, simultaneous consideration of grain yield and ASV in single non-parametric index is needed. Accordingly, EH06079-7 (16.32 Qt/ha) and EH00016-2 (16.74Qt/ha) genotypes were found to be higher yielder genotypes and relatively stable.

Table6. AMMI stability value, genotype selection index, yield rank and principal component axis

\begin{tabular}{|c|c|c|c|c|c|c|c|c|}
\hline Gen & Genotype & Mean & PC1 & PC2 & ASV & ASV Rank & Yd. Rank & GSI \\
\hline G1 & Ek02016-1-4 & 13.13 & 1.2417 & 0.2811 & 1.94289 & 8 & 13 & 21 \\
\hline G2 & EK02018-1 & 14.26 & 1.4251 & -0.2220 & 2.217584 & 9 & 9 & 18 \\
\hline G3 & EH06005-1 & 14.31 & 0.7322 & 0.8668 & 1.42708 & 5 & 8 & 13 \\
\hline G4 & Ek 01019-7-1 & 14.9 & -1.552 & 0.5293 & 2.461124 & 13 & 6 & 19 \\
\hline G5 & Local check & 13.71 & -0.407 & 1.3498 & 1.49024 & 6 & 11 & 17 \\
\hline G6 & EH00126-2 & 13.5 & 0.5468 & 0.3888 & 0.93169 & 4 & 12 & 16 \\
\hline G7 & EKLS01022-1 & 14.73 & -1.151 & 0.3904 & 1.82429 & 7 & 7 & 14 \\
\hline G8 & EH00009-3 & 12.44 & 1.7860 & 0.1113 & 2.76732 & 14 & 14 & 28 \\
\hline G9 & EKIsr01009-2-2 & 14.06 & 0.3170 & -0.2319 & 0.54289 & 1 & 10 & 11 \\
\hline
\end{tabular}

International Journal of Research Studies in Agricultural Sciences (IJRSAS)

Page $\mid 40$ 
Analysis of Genotype by Environmental Interaction and Stability for Grain Yield of Faba Bean (Vicia Faba L.) Genotypes in West and Kellem Wollega Zones of Western Oromia

\begin{tabular}{|l|c|c|c|c|c|c|c|c|}
\hline G10 & EH00016-2 & 16.74 & -1.460 & 0.7573 & 2.38832 & 11 & 1 & 12 \\
\hline G11 & Moti & 15.87 & -0.152 & -2.3739 & 2.38568 & 10 & 5 & 15 \\
\hline G12 & EH06079-7 & 16.32 & 0.3168 & -0.6193 & 0.79012 & 3 & 2 & 5 \\
\hline G13 & EH000012-4 & 16.18 & -1.218 & -1.5561 & 2.44558 & 12 & 3 & 15 \\
\hline G14 & Shalo & 15.88 & -0.420 & 0.32842 & 0.72892 & 2 & 4 & 6 \\
\hline
\end{tabular}

\subsection{Genotypes and Genotypes by Environment Interaction (GGE) Bi-Plot Analysis}

GGE biplot is a pictorial representation which describes the stability of the genotypes and environment based on the IPCA scores. As the vertex cultivar is the highest-yielding cultivar in all environments that share the sector with it, G11 fell in two environments and was high yielding in respective environments for instance. Besides, no environments fell in the sectors with G8 as vertex cultivars showing that the vertex cultivar was not the best in any of the test environments. On the other terms, this indicates that the cultivar was the poorest in some or all of the environments. A cultivar located at the origin would rank the same in all environments and is not at all responsive to the environments.

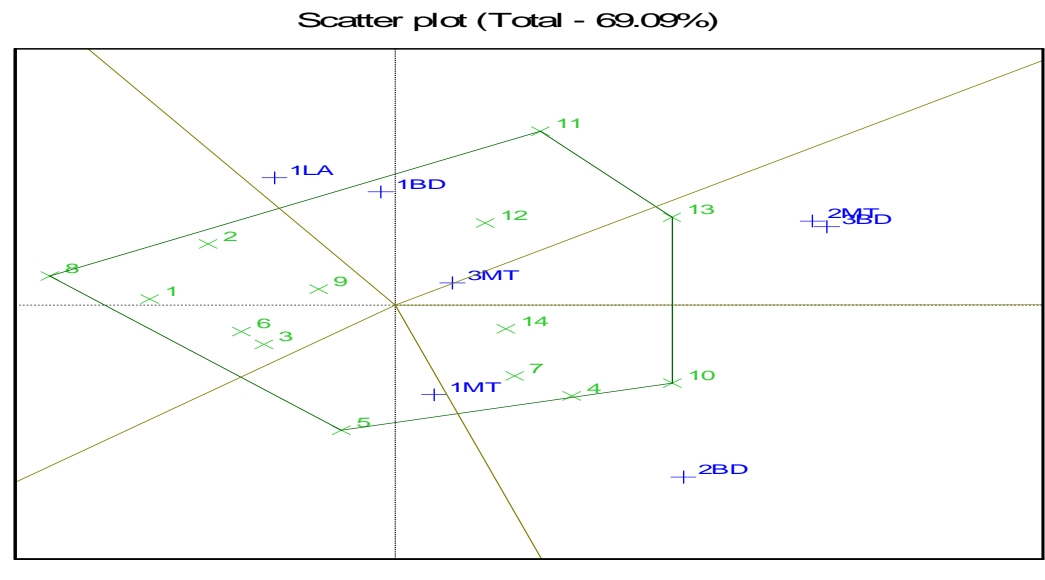

PC1 - 46.26\%

Scatter plot (Total - 69.09\%)

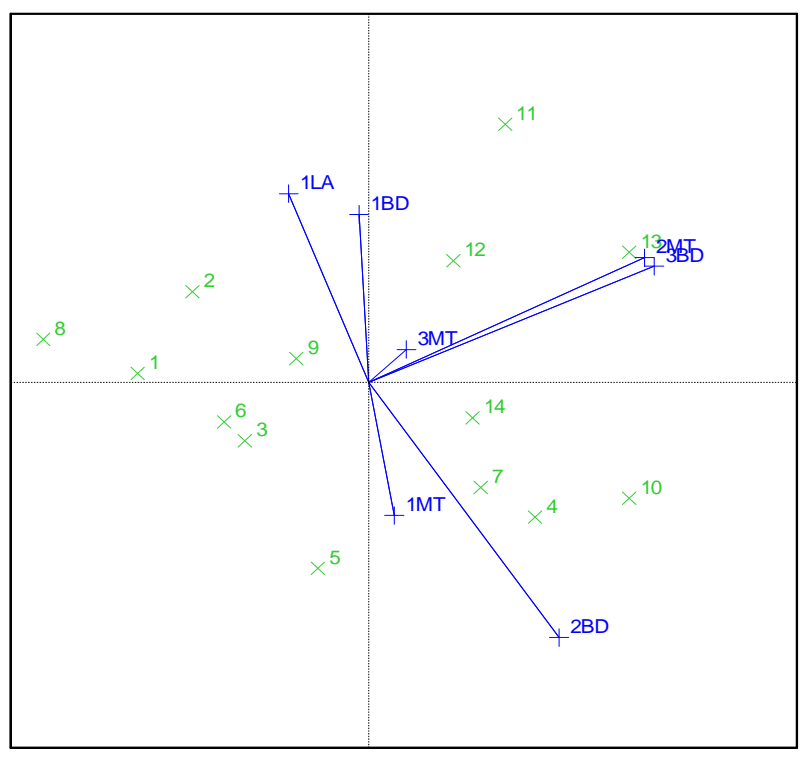

PC1 - 46.26\%

\begin{tabular}{cl|}
\hline$\times$ & Genotype scores \\
+ & Environment scores \\
\hline
\end{tabular}

Figure1. Scatter biplot "Which won where" analysis, where G indicates genotyppes, $B D=$ Badesso, $L A=$ Lalo Asab, MT= Mata 


\subsection{GGE Bi-Plot Analysis for Comparison of Genotype for Grain Yield Potential and Stability}

In GGE biplot, the environments and genotypes obtained in the concentric (central circle) are considered as ideal environments and stable genotypes, respectively (Yan, 2002). Using the ideal genotype as the center, concentric circles were drawn to help visualize the distance between each genotype and the ideal variety. Therefore, ranking based on the genotypes-focused scaling, assumes that stability and mean yield are equally important (Farshadfar et al., 2011). Genotype G13 followed by G10 and G12 were lied relatively near to the center of concentric circles were ideal genotypes in terms of yield and stability (Figure 2). Similarly, Tamane et al. (2016) identified the best genotypes which had superior grain yield and yield stability.
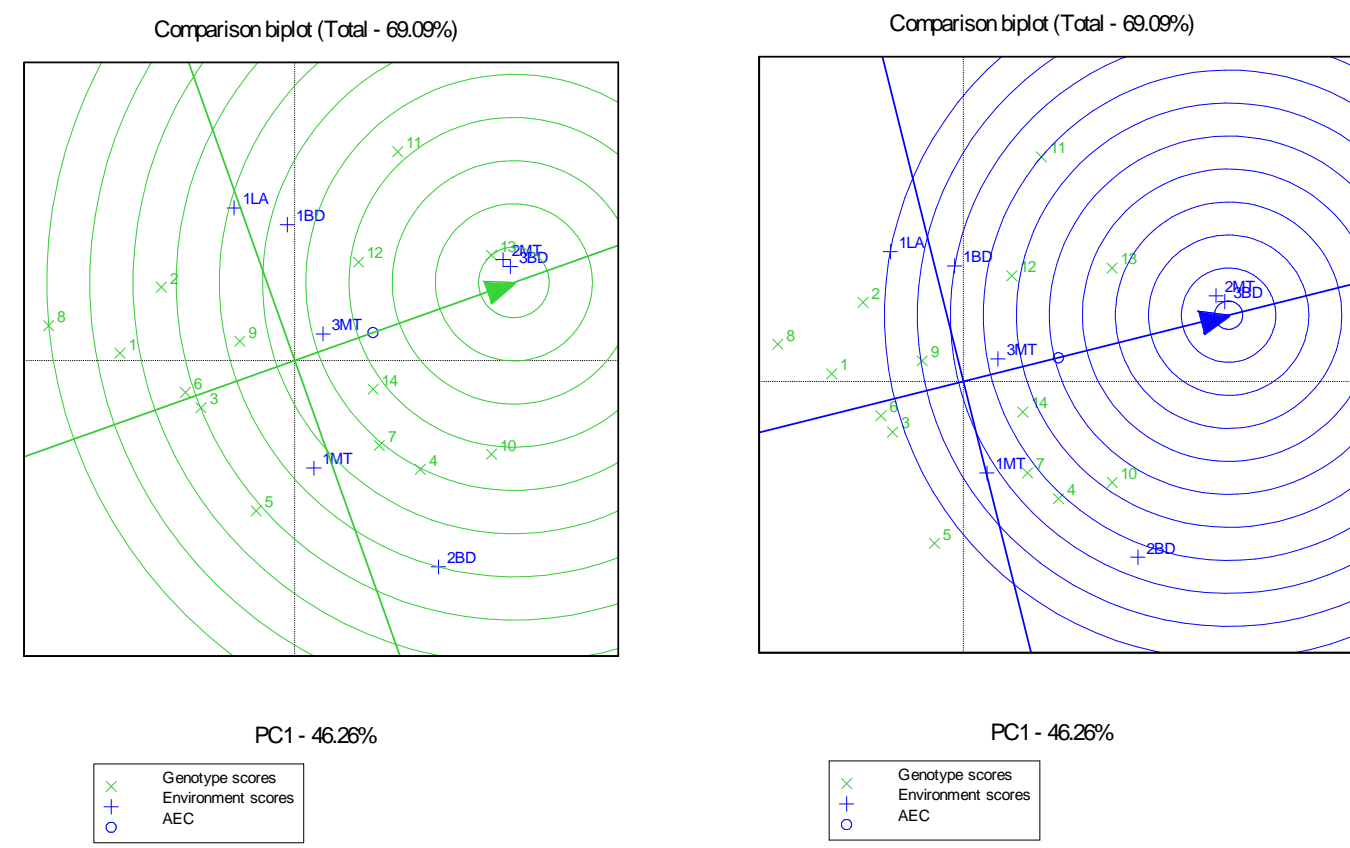

Figure2. GGE bi-plot for comparison of genotype and environment for grain yield potential and stability.

\section{CONCLUSION}

Combined ANOVA detected significant variation among genotypes, environments and their interaction. AMMI biplot, ASV, GSI and GGE Biplot further confirmed that G10 and G12 were most stable and widely adapted, whereas G13 had stable coupled with relative higher yield performance. Therefore, G10 and 12 was selected as the candidate genotypes and suggested for possible release as new variety of faba bean for West and Kellem Wollega zones of western Oromia and areas with similar agro-ecology.

\section{ACKNOWLEDGEMENT}

Author would like to thank Oromia Agricultural Research Institute for granting financial support, Haro Sabu Agricultural Research Center for this research work facilitation and Pulse and Oil crop research team for all their effort from field work to office.

\section{REFERENCES}

[1] A. M.Gezahegn, K.Tesfaye, J. J. Sharma and M. D. Belel, "Determination of optimum plant density for faba bean (Vicia faba L.) on vertisols at Haramaya, Eastern Ethiopia," Cogent Food and Agriculture, 2(1), $1224485,2016$.

[2] E. Abebe, T. Mekete, A.Seid and B.H.Meressa, Wondafrash, M., Addis, T. and Abate, B. A, "Research on plant-parasitic and entomopathogenic nematodes in Ethiopia: a review of current state and future direction," Nematology, 17(7), 741-759, 2015.

[3] E.Farshadfar, H. Zali, and R, Mohammadi, "Evaluation of phenotypic stability in chickpea genotypes using GGE-Biplot," Ann. Biol. Res, 2, 282-292, 2011.

[4] K. A. Gomez and A. A. Gomez, "Statistical Procedures for Agricultural Research. 2nd Ed., John Willey and Sons. Singapore," 1984. 
[5] L.K.. Bose, N.N. JAMBHULKAR, K. PANDE, O.N. SINGH, "Use of AMMI and other stability statistics in the simultaneous selection of rice genotypes for yield and stability under direct seeded conditions," Chilean Journal of Agricultural Research, 74(1): 3-9, 2014.

[6] SAS, “Guide for personal computers Version 9.0 Edition, SAS institute Inc., Cary, NC”, 2006.

[7] T.Hagos and A. Fetien, "Additive Main Effects and Multiplicative Interactions Analysis of Yield Performance of Sesame Genotypes across Environments in Northern Ethiopia," Journalof the Drylands 4(1): 259-266, 2011.

[8] T.Tamene, K. Gemechu and M.Hussein, "Genetic progresses from over three decades of faba bean (Vicia faba L.) breeding in Ethiopia," Australia Journal of crop science, 9:41-48, 2015.

[9] T. Tolessa and K. Gemechu and M. Hussein, "Genetic progresses from over three decades of faba bean (Vicia faba L.) breeding in Ethiopia," Australian Journal of Crop Science, 9. 41-48, 2015.

[10] W.Yan, and L.A. Hunt, "Biplot analysis of multi-environment trial data, In M. S. Kang, ed. Quantitative Genetics, Genomics and Plant Breeding. CAB International, Willingford," 2002.

[11] Y.Desta, K..Habtegebrial and Y.Weldu, "Inoculation, phosphorous and zinc fertilization effects on nodulation, yield and nutrient uptake of Faba bean (Vicia faba L.) grown on calcaric cambisol of semiarid Ethiopia," Journal of Soil Science and Environmental Management, 6(1), 9-15, 2015.

Citation: Dereje Abera, et.al, "Analysis of Genotype by Environmental Interaction and Stability for Grain Yield of Faba Bean (Vicia Faba L.) Genotypes in West and Kellem Wollega Zones of Western Oromia" International Journal of Research Studies in Agricultural Sciences (IJRSAS), 2019; 5(7), pp. 37-43, http://dx.doi.org/10.20431/2454-6224.0507004

Copyright: (C) 2019 Authors. This is an open-access article distributed under the terms of the Creative Commons Attribution License, which permits unrestricted use, distribution, and reproduction in any medium, provided the original author and source are credited. 